\title{
OPEN Author Correction: Shape fidelity and structure of 3D printed high consistency nanocellulose
}

\section{Ville Klar@i, Jaakko Pere, Tuomas Turpeinen, Pyry Kärki, Hannes Orelma \& Petri Kuosmanen}

Correction to: Scientific Reports https://doi.org/10.1038/s41598-019-40469-x, published online 07 March 2019

In the Supplementary Information file originally published with this Article, the equations for the plots were erroneous. These errors have been corrected in the Supplementary Information that now accompanies the Article.

Additionally, this Article contained a typographical error in the Methods section under subheading 'Printing.' where,

"We establish an approximate drying time with a one term polynomial fit performed on the drying data."

now reads:

"We establish an approximate drying time with an exponential decay model fit performed on the drying data."

This error has now been corrected in the HTML and PDF versions of the Article.

(i) Open Access This article is licensed under a Creative Commons Attribution 4.0 International License, which permits use, sharing, adaptation, distribution and reproduction in any medium or format, as long as you give appropriate credit to the original author(s) and the source, provide a link to the Creative Commons license, and indicate if changes were made. The images or other third party material in this article are included in the article's Creative Commons license, unless indicated otherwise in a credit line to the material. If material is not included in the article's Creative Commons license and your intended use is not permitted by statutory regulation or exceeds the permitted use, you will need to obtain permission directly from the copyright holder. To view a copy of this license, visit http://creativecommons.org/licenses/by/4.0/.

(C) The Author(s) 2020 